\title{
Bone Marrow Examination in Cases of Pancytopenia
}

Jha A, Sayami G, Adhikari RC, Panta AD, Jha R,

Department of Pathology, Institute of Medicine, TUTH.

\section{ABSTRACT}

This study was carried to identify the causes of pancytopenia and to find out the bone marrow morphology in cases of pancytopenia.

It was a cross sectional study conducted over a period of two years in the Department of Pathology, Tribhuvan University Teaching Hospital. Bone marrow aspiration smears of patients fulfilling the criteria of pancytopenia were examined. The data obtained were analyzed using measures of central tendency.

One hundred and forty eight cases underwent bone marrow aspiration and it constituted $15.74 \%$ of total cases. Mean age was 30 years (range, $1-79$ years). 42 cases were children (28.37\%). Male: female ratio was 1.5:1. The commonest cause was hypoplastic bone marrow seen in 43 cases (29\%) followed by megaloblastic anemia in 35 cases $(23.64 \%)$, and hematological malignancy in 32 cases (21.62\%). Erythroid hyperplasia was seen in 29 cases (19.6\%) and normal bone marrow was seen in 5 cases $(3.38 \%)$. There was one case each of Niemann-Pick disease and metastatic neuroblastoma in children and chronic pure red cell aplasia and leishmaniasis in adults. Acute leukemia was the commonest hematological malignancy. In children, commonest finding was hypoplastic bone marrow (38.1\%) while in adults megaloblastic anemia (30.18\%) was commonest finding followed by hypoplastic anemia (25.47\%).

In present study bone marrow examination was able to establish diagnosis in $77 \%$ of cases. Hypoplastic marrow was the commonest diagnosis, followed by megaloblastic anemia, and hematological malignancies.

Key Words: Bone marrow aspiration, hypoplastic anemia, leukemia, megaloblastic anemia, pancytopenia, 


\section{INTRODUCTION}

Pancytopenia is defined by reduction of all the three formed elements of blood below the normal reference range. ${ }^{1}$ The presenting symptoms are often attributable to the anemia or the thrombocytopenia. Leucopenia is often seen in the subsequent course of the disorder. ${ }^{2}$ Varieties of hematopoietic and non-hematopoietic conditions manifest with features of pancytopenia. The underlying mechanisms are decrease in hematopoietic cell production, marrow replacement by abnormal cells, suppression of marrow growth and differentiation, ineffective hematopoiesis with cell death, defective cells formation which are removed from the circulation, antibody mediated sequestration or destruction of cells, and trapping of cells in a hypertrophied and overactive reticuloendothelial system. ${ }^{1,3}$

In cases of ineffective hematopoiesis the marrow may be normocellular or hypercellular. ${ }^{1}$ Bone marrow examination is extremely helpful in evaluation of pancytopenia. ${ }^{4}$ Few similar studies have been published in the country. ${ }^{5}$ This study was carried out with an aim to obtain further information so that it would help in the management of patient with pancytopenia.

\section{MATERIALS AND METHODS}

The present study was a cross-sectional study, conducted at the Department of Pathology, Tribhuvan University Teaching Hospital (TUTH), Kathmandu, Nepal, over a period of 2 years (April 2005 to March 2007). The inclusion criteria for pancytopenia were hemoglobin $(\mathrm{Hb})$ less than $10 \mathrm{gm} / \mathrm{dL}$, total leukocyte count (TLC) less than $4000 /$ cumm and platelet count less than 140000 /cumm. ${ }^{3,6}$ Cases fulfilling the definition of pancytopenia but lacking marrow representative bone marrow in the marrow aspirate were also excluded from the study. In each case bone marrow aspiration
(BMA) was performed by the standard technique using Salah needle, from the posterior iliac crest under local anesthesia with standard aseptic precautions. Wright stain was used to stain all bone marrow smears. When required cytochemical stains such as Periodic-Acid Schiff (PAS) and Myeloperoxidase (MPO) stains were also used. The necessary hematological and clinical parameters were also noted.

\section{RESULTS}

The total number of bone marrow examination (BMEs) performed over two years for various indications at the Department of Pathology was 940. In 163 (17.34\%) cases, bone marrow examination was performed for the indication of pancytopenia. Fifteen cases were excluded from the study as there was no representative marrow in the smears. Thus the total number of cases included in the study was $148(15.74 \%)$. There were 89 males and 59 females with male: female ratio of $1.5: 1$. The mean age was 30 years with range of 1 - 79 years. Bone marrow aspiration findings and distribution of the patients are shown in Table 1 . In cases of hypoplastic bone marrow, 25 cases were male and 18 cases were female with male: female ratio of $1.3: 1$. The age ranged from 1.5- 70 years (median 17 years). In cases of megaloblastic anemia, 21 were male and 14 were female with male: female ratio of 1.5:1. The age ranged from ten to seventy nine years (median 31 years).

Hematological malignancies are shown in Table 2, Acute leukemia alone constituted $90.62 \%$ of all hematological malignancies. Nine cases were acute lymphoblastic leukemia (ALL) and 20 cases were acute myeloid leukemia (AML). In cases of acute leukemia age ranged from 2- 75 years with median of a 22 years. The male: female ratio was 1.9:1. The patient profile and hematological parameters of $A L L$ and $A M L$ are

Table 1. Bone marrow aspiration findings in cases of pancytopenia

\begin{tabular}{lcc}
\hline Bone marrow findings & Number of cases & Percentage \\
\hline Hypoplastic bone marrow & 43 & 29.05 \\
Megaloblastic anemia & 35 & 23.64 \\
Hematological malignancies & 32 & 21.62 \\
Erythroid hyperplasia & 29 & 19.6 \\
Normal bone marrow & 05 & 3.38 \\
Metastatic neuroblastoma & 01 & 0.67 \\
Niemann Pick disease & 01 & 0.67 \\
Chronic pure red cell aplasia (PRCA) & 01 & 0.67 \\
Leishmaniasis & 01 & 0.67 \\
Total & 148 & 100 \\
\hline
\end{tabular}


Table 2. Hematological malignancies in cases of pancytopenia

\begin{tabular}{lcc}
\hline Hematological malignancies & Number of cases & Percentage \\
\hline Acute myeloid leukemia (AML) & 20 & 62.5 \\
Acute lymphoblastic leukemia (ALL) & 09 & 28.12 \\
Plasma cell myeloma & 01 & 3.12 \\
Non-Hodgkin lymphoma (NHL) & 01 & 3.12 \\
Myelodysplastic syndrome: RAEB-2 & 01 & 3.12 \\
Total & 32 & 100 \\
\hline
\end{tabular}

Table 3. Patient profile and hematological parameters of ALL and AML in cases of pancytopenia

\begin{tabular}{|c|c|c|c|}
\hline & Parameters & ALL & AML \\
\hline M: F & & 3.5 & 1.5 \\
\hline \multirow{2}{*}{ Age (Years) } & Median & 13 & 29 \\
\hline & Range & $2-33$ & $2-75$ \\
\hline \multirow[t]{2}{*}{$\mathrm{Hb}(\mathrm{gm} / \mathrm{dL})$} & Median & 6.81 & 5.45 \\
\hline & Range & $2.3-9.31$ & $1.2-9.6$ \\
\hline \multirow[t]{2}{*}{ TLC (per $\left.\mathrm{mm}^{3}\right)$} & Median & 1800 & 1950 \\
\hline & Range & $900-3800$ & $800-3600$ \\
\hline \multirow[t]{2}{*}{ Platelet (per $\mathrm{mm}^{3}$ ) } & Median & 40000 & 37500 \\
\hline & Range & $4000-100000$ & $6000-125000$ \\
\hline
\end{tabular}

Table 4. A comparison of age and common hematological parameters in 4 common bone marrow findings in cases of pancytopenia

\begin{tabular}{|c|c|c|c|c|}
\hline Parameters & $\begin{array}{l}\text { Hypoplastic marrow } \\
\text { Range (median) }\end{array}$ & $\begin{array}{l}\text { Megaloblastic anemia } \\
\text { Range (median) }\end{array}$ & $\begin{array}{c}\text { Hematological } \\
\text { malignancies Range } \\
\text { (median) }\end{array}$ & $\begin{array}{c}\text { Erythroid hyperplasia } \\
\text { Range (median) }\end{array}$ \\
\hline Age (Years) & $1.5-70(17)$ & $10-79(31)$ & $2-75(22)$ & $1-71(26)$ \\
\hline $\mathrm{Hb}(\mathrm{gm} / \mathrm{dL})$ & $2-9.5(5.9)$ & $2.3-9.8(6.2)$ & $1.2-9.6(5.8)$ & $2.2-9.8(7.5)$ \\
\hline TLC (per $\left.\mathrm{mm}^{3}\right)$ & $900-3800$ (2400) & $1200-3900(2600)$ & $800-3800(2000)$ & $1000-3700(2800)$ \\
\hline Platelet (per $\mathrm{mm}^{3}$ ) & $\begin{array}{c}1000-136000 \\
(30000)\end{array}$ & $\begin{array}{c}2000-137000 \\
(50000)\end{array}$ & $\begin{array}{c}4000-125000 \\
(40000)\end{array}$ & $\begin{array}{c}2000-139000 \\
(50000)\end{array}$ \\
\hline
\end{tabular}

compared in Table 3. AML-M2 was the most common type of AML ( $n=12)$ followed by AML-M3 $(n=5)$, AMLM4 $(n=2), A M L-M 5$ and AML-M6 one each. There were five cases of ALL-L1 and four cases of ALL-L2.

A comparison of age of the patients and hematological parameters of four major bone marrow findings are show in Table 4 . In the pediatric age group $(\leq 14$ years) hypoplastic anemia was the commonest findings followed by erythroid hyperplasia, acute leukemia, while megaloblastic anemia was fourth most common (Table 5). In adults (15 years and above), megaloblastic anemia was the most common finding followed by hypoplastic marrow, hematological malignancy and erythroid hyperplasia.

\section{DISCUSSION}

Bone marrow examination for the evaluation of pancytopenia is a frequently requested investigation. In the present study, $17.34 \%$ of the total BMA cases was indicated for evaluation of pancytopenia. However, $15.74 \%$ cases were enrolled in this study. In a study conducted by Bashawri et al, the frequency of BME for evaluation of pancytopenia was $11.9 \% .^{7}$ Bone marrow 
Table 5. Comparison of bone marrow aspiration findings in children and adults

\begin{tabular}{|c|c|c|c|c|}
\hline \multirow{2}{*}{ Bone marrow findings } & \multicolumn{2}{|c|}{ Children( $\leq 15$ Years) } & \multicolumn{2}{|c|}{ Adult ( $\geq 15$ years) } \\
\hline & No. of cases & $\%$ & No. of cases & $\%$ \\
\hline Hypoplastic bone marrow & 16 & 38.1 & 27 & 25.47 \\
\hline Erytheroid hyperplasia & 10 & 23.8 & 19 & 18 \\
\hline ALL & 06 & 14.28 & 03 & 2.83 \\
\hline AML & 03 & 7.14 & 17 & 16.03 \\
\hline Megaloblastic anemia & 03 & 7.14 & 32 & 30.18 \\
\hline Normal & 02 & 4.76 & 03 & 2.83 \\
\hline Niemann Pick Disease & 01 & 2.38 & 00 & 00 \\
\hline Metastatic neuroblastoma & 01 & 2.38 & 00 & 00 \\
\hline Plasma cell myeloma & 00 & 00 & 01 & 0.94 \\
\hline Non-Hodgkin Iymphoma & 00 & 00 & 01 & 0.94 \\
\hline Myelodysplastic syndrome: RAEB-2 & 00 & 00 & 01 & 0.94 \\
\hline Chronic pure red cell aplasia (PRCA) & 00 & 00 & 01 & 0.94 \\
\hline Leishmaniasis & 00 & 00 & 01 & 0.94 \\
\hline Total & 42 & 100 & 106 & 100 \\
\hline
\end{tabular}

Table 6. A comparison of the first and second most common causes of pancytopenia in different studies

\begin{tabular}{|c|c|c|c|c|c|}
\hline Study & Country & Year & $\begin{array}{l}\text { No. of } \\
\text { cases }\end{array}$ & Commonest cause & $\begin{array}{l}\text { Second most } \\
\text { common cause }\end{array}$ \\
\hline $\begin{array}{l}\text { International agranulocytosis and } \\
\text { Aplastic anemia study group }{ }^{8}\end{array}$ & $\begin{array}{l}\text { Israel \& } \\
\text { Europe }\end{array}$ & 1987 & 319 & $\begin{array}{l}\text { Hypoplastic anemia } \\
(52.7 \%)\end{array}$ & $\operatorname{MDS}(4.5 \%)$ \\
\hline Keisu and Ost ${ }^{9}$ & $\begin{array}{l}\text { Israel \& } \\
\text { Europe }\end{array}$ & 1990 & 100 & $\begin{array}{l}\text { Neoplastic disease, } \\
\text { radiation }(32 \%)\end{array}$ & $\begin{array}{l}\text { Hypoplastic anemia } \\
(19 \%)\end{array}$ \\
\hline Hossain et $\mathrm{al}^{10}$ & Bangladesh & 1992 & 50 & Hypoplastic anemia & $\begin{array}{l}\text { Chronic malaria and } \\
\text { chronic kalazar }\end{array}$ \\
\hline Verma and Dash ${ }^{4}$ & India & 1992 & 202 & $\begin{array}{l}\text { Hypoplastic anemia } \\
(40.6 \%)\end{array}$ & $\begin{array}{l}\text { Megaloblastic } \\
\text { anemia }(23.26 \%)\end{array}$ \\
\hline Tilak and Jain ${ }^{11}$ & India & 1999 & 77 & $\begin{array}{l}\text { Megaloblastic } \\
\text { anemia }(68 \%)\end{array}$ & $\begin{array}{l}\text { Hypoplastic anemia } \\
(7.7 \%)\end{array}$ \\
\hline Kumar et $\mathrm{al}^{6}$ & India & 1999 & 166 & $\begin{array}{l}\text { Hypoplastic anemia } \\
(29.51 \%)\end{array}$ & $\begin{array}{l}\text { Megaloblastic } \\
\text { anemia }(22.3 \%)\end{array}$ \\
\hline Khodke et al ${ }^{3}$ & India & 2000 & 50 & $\begin{array}{l}\text { Megaloblastic } \\
\text { anemia }(44 \%)\end{array}$ & $\begin{array}{l}\text { Hypoplastic anemia } \\
(14 \%)\end{array}$ \\
\hline Bajracharyaet $\mathrm{al}^{5}$ & Nepal & 2005 & 10 & $\begin{array}{l}\text { Hypoplastic anemia } \\
(\%)\end{array}$ & $\begin{array}{l}\text { Megaloblastic } \\
\text { anemia }(\%)\end{array}$ \\
\hline Present study & Nepal & 2007 & 148 & $\begin{array}{l}\text { Hypoplastic anemia } \\
(29.05 \%)\end{array}$ & $\begin{array}{l}\text { Megaloblastic } \\
\text { anemia }(23.64 \%)\end{array}$ \\
\hline
\end{tabular}

in such patients may be hypocellular, normocellular or even hypercellular. ${ }^{1}$

In the present study, BME alone provided specific diagnosis in $77 \%$ of cases (Table 1 \& 2). The commonest bone marrow finding was hypoplastic anemia followed by megaloblastic anemia. The frequency of various diagnostic entities causing pancytopenia has been attributed to differences in the methodology and stringency of diagnostic criteria, geographic differences, 
and underlying exposure to myelotoxic drugs. ${ }^{8}$ However, there is limited data regarding this from Nepal. ${ }^{5}$ The first two common causes of pancytopenia in different studies are compared in Table 6. ${ }^{3-6,8-11}$ In a study by Savage et al and Khunger et al the most common causes of pancytopenia were megaloblastic anemia, followed by hypoplastic anemia and acute leukemia was the third most common in the former study. ${ }^{12,13}$ In the present study the frequency of various diagnostic entities seen in the cases of pancytopenia in $\leq 15$ years of age and $\geq 15$ years of age is shown in Table 5 . In a study conducted by Bhatnagar et al in children, megaloblastic anemia was the commonest cause of pancytopenia $(28.4 \%)$ followed by acute leukemia $(21 \%)$ and hypoplastic anemia (20\%). ${ }^{14}$ Hematological parameters in the major causes of pancytopenia show overlap without any clue to diagnosis (Table 4). Similar results have been obtained by Kumar et al. ${ }^{6}$

In the present study the diagnosis of hypoplastic anemia in all 43 cases was given based on BMA findings and only in 22 was cases bone marrow biopsy available. It is recommended that both aspiration and trephine biopsy be done simultaneously in cases of pancytopenia. ${ }^{6}$ Aspiration smears are superior for morphological details while biopsy provides a more reliable index of cellularity and often reveals bone marrow infiltration, fibrosis and granulomas. ${ }^{6}$ Occasionally, in cases of hypoplastic anemia marrow may be very cellular but the smears show depleted megakaryocytes, which is because of a regenerating focus called "Hot spot". In such a situation, bone marrow biopsy can be diagnostic. ${ }^{1}$

Megaloblastic anemia was a common diagnosis in the present study as well as in other studies. ${ }^{3,11,14}$ In the present study, we could not identify the exact deficiency leading to megaloblastic anemia as serum folic acid or vitamin B12 levels were not assessed. The higher numbers of megaloblastic anemia seem to reflect higher a prevalence of nutritional deficiency in our country. Acute megaloblastic anemia is an important cause of pancytopenia occurring rapidly in critically ill patients due to acute folic acid deficiency. ${ }^{6}$

In the present study, hematological malignancy as a cause pancytopenia was found in significant numbers. The most common condition was acute leukemia. In children, acute leukemia was the only hematological malignancy, while in the adult, acute leukemia constituted 20 out of 23. Plasma cell myeloma, MDS and NHL were the other three hematological malignancies in adults, as in other studies where they were not in significant number. ${ }^{3,5,6,11}$ The overall frequency of hematological malignancy in the pediatric age group and in adults was similar $121.42 \%$ versus $21.68 \%$ ). Acute leukemia alone constituted $19.59 \%$ of the total cases of pancytopenia in contrast to the study by Kumar et al where no acute leukemia was detected. ${ }^{6}$ Similarly, in the studies by Khodke et al and Tilak et al one case of AML was detected as a cause of pancytopenia. ${ }^{3,11}$ Nevertheless, in the study of Bashawri the main indication for BME in cases of pancytopenia was investigation of acute leukemia. ${ }^{7}$ Acute leukemia was the third common cause of pancytopenia in the study of Varma and Dash. ${ }^{4}$ Similarly, in the study of Savage et al in Zimbabwe, acute leukemia constituted the third most common cause of pancytopenia. In their study, patients with hypoplastic anemia and acute leukemia were usually children, whereas those with megaloblastic anemia were adults, ${ }^{12}$ similar to this study (Table 5). ALL was the commonest acute leukemia in the pediatric age while $A M L$ was the commonest in adults. Only three cases of ALL (two cases of ALL-L2 and one case of ALL-L1) were seen in dults. And this finding supports the well-established finding that ALL is common in children (Table 3). ALL-L1 was the most common type of ALL while AML-M2 was the most common type of $A M L$, and most of them were seen in adults. In children, one case each of AML-M2, AML-M3 and AML-M4 were seen. Hematological parameters of ALL and AML show considerable overlap (Table 3).

Erythroid hyperplasia was one of the common findings in the present study and its relationship to pancytopenia is uncertain. Some of these cases may represent one phase in the evolution of hypoplasia, while some may be cases of refractory anemia. The criteria for differentiation of these groups remain unsatisfactory and these patients should be kept under follow-up. ${ }^{3}$ Hypercellular or normocellular marrow in cases of pancytopenia can also be seen in cases with ineffective hematopoiesis with cell death within the marrow. ${ }^{1}$ Similarly, hypercellular marrow in the presence of peripheral pancytopenia can be a manifestation of paraneoplastic syndrome. ${ }^{15}$

Leishmaniasis was seen in only one case, but it is not a rare finding in the studies from India. ${ }^{3,6,11}$ Metastatic neuroblastoma and Niemann-Pick disease were rare causes of pancytopenia in the present study. Another rare but interesting finding in this study was chronic PRCA causing pancytopenia. Chronic PRCA usually manifests as anemia but rarely can have pancytopenia. ${ }^{1}$

\section{CONCLUSION}

BME is an established diagnostic modality in the evaluation of pancytopenia. BME in most cases gives the specific diagnosis. However, in a few cases, additional tests are required. In the present study, BME was able to establish the diagnosis in $77 \%$ of cases. Hypoplastic marrow was the commonest diagnosis, followed by megaloblastic anemia, and hematological malignancies. However, in adults, megaloblastic anemia was the commonest finding followed by hypoplastic anemia. Rare causes included metastatic neuroblastoma, chronic PRCA, Niemann-Pick disease and leishmaniasis. Hypercellular marrow with erythroid hyperplasia and normal marrow were seen in $19.6 \%$ and $3.38 \%$ of cases respectively, which may require additional tests. 


\section{REFERENCES}

1. Williams DM. Pancytopenia, Aplastic anemia and Pure red cell aplasia. In: Wintrobe's Clinical Hematology, $10^{\text {th }}$ ed. Baltimore: William and Willkins; 1993.14491484.

2. Firkin F, Chesterman C, Penington D, Rush B. de Gruchy's Clinical haematology in Medical Practice. $5^{\text {th }}$ ed. London: Blackwell Scientific Publications; 1989. 119-136.

3. Khodke K, Marwah S, Buxi G, Yadav RB, Chaturvedi NK. Bone Marrow Examination in Cases of Pancytopenia. JIACM 2001;2:55-59.

4. Varma N, DashS. A reappraisal of underlying pathology in adult patients presenting with pancytopenia. Trop Geogr Med 1992;44:322-7.

5. Bajracharya SB, Pande R, Bhandari PB, Sinha R, Guragain P. An Approach to Aplastic anemia. Medical Journal of Shree Birendra Hospital. The Journal of the Royal Nepalese Army Medical Corps 2005;7:82-83.

6. Kumar R, Kalra SP, Kumar H, Anand AC, Madan H. Pancytopenia - A six year Study. JAPI 2001;49:10781081.

7. Bashwri LA. Bone marrow examination. Indications and diagnostic value. Saudi Medi J. 2002;23:191-6.

8. International agranulocytosis and aplastic anemia study. Incidence of aplastic anemia, the relevance of diagnostic criteria. Blood 1987;70:1718-21.

9. Keisu M, Ost A. Diagnosis in patients with severe pancytopenia suspected of having aplastic anemia. Eur J Haematol 1990;45:11-4.

10. Hossain MA, Akond AK, Chowdhary MK et al. Pancytopenia-A study of 50 cases. Bangladesh Journal of Pathology 1992;1:9-12.

11. Tilak V, Jain R. Pancytopenia - A clinico-hematologic Analysis of 77 cases. Indian J Pathol Microbiol 1999;42:399-404.

12. Savage DG, Allen RH, Gangaidzo IT et al. Pancytopenia in Zibabwe. Am J Med Sci 1999;317:22-32.

13. Khunger JM, Arulsevi S, Sharma U, Ranga S, Talib VH. Pancytopenia - a clinicohematological study of 200 cases. Indian J Pathol Microbiol 2002;45:375-9.

14. Bhatnagar SK, Chandra J, Narayan S, Sharma S, Singh V, Dutta AK. Pancytopenia in children: Etiological profile. J Trop Pediatr 2005;51:236-9.

15. Raz I, Shinar E, Polliack A. Pancytopenia with Hypercellular bone marrow- a possible paraneoplastic syndrome in carcinoma of the lung: a report of three cases. Am J Hematol 1984;16:403-8. 